\title{
APONTAMENTOS SOBRE FORMAS ALTERNATIVAS DE REAFRICANIZAÇÃO EM TERREIROS DE BATUQUE NO RIO GRANDE DO SUL, ARGENTINA E URUGUAI
}

\author{
Daniel Francisco de Bem ${ }^{1}$
}

Resumo: Nas últimas décadas tem ampliado a importância e visibilidade do processo de reafricanização entre populaçóes negras e grupos com práticas culturais de ascendência africana. Entre os adeptos das religiōes de matriz ou presença africana, não é diferente. A partir do estudo do sistema religioso batuqueiro em uma escala transnacional, este texto versa sobre algumas formas alternativas com as quais afro-religiosos do Rio Grande do Sul, Argentina e Uruguai têm se inserido nesse processo tanto no campo religioso quanto político, em busca da purificação de seus rituais e de uma participação nas respectivas esferas públicas locais e nacionais que permita a visibilidade, legitimação e respeito de uma religiosidade singularidade pela sua referência a uma origem e uma ontologia relativas às etnias negras e a África.

Palavras-chave: Religiōes afro-brasileiras; transnacionalização religiosa; reafricanização; identidades afro-americanas.

Abstract: The importance and visibility of the reafricanization process between black populations and groups with cultural practices of African's heritage in last decades has amplified. Between the follower of African's matrix or presence this is not different. From the study on the batuque religion system on an transnational scale, this text tackle some alternatives forms which African-Brazilian religious of Rio Grande do Sul, Argentina and Uruguay have been inserted in this religious as much as political process, looking for purify yours rituals and participating on local and national public space with visibility, legitimacy and respect for an singular religiosity with reference to an origin and an ontology relatives to black ethnics and to Africa.

Keywords: African-Brazilian religions; religious transnationalization; reafricanization; African-American identities.

Desde de 2005 enquanto antropólogo estudioso dos fluxos afro-religiosos entre o estado brasileiro do Rio Grande do Sul e os estados-naçôes

${ }^{1}$ Doutorando em Antropologia Social (PPGAS/UFRGS), bolsista de doutorado CAPES.

Debates do NER, Porto Alegre, Ano io, N. I6, P. 20I-224, JUl./Dez. 2009 
da Argentina e Uruguai, fui aprofundando-me em uma dupla compreensão sobre a organização dessa cena religiosa transnacional. Por um lado, sabe-se da importância da ação de vários pais-de-santo gaúchos, sul-brasileiros, porto-alegrenses e fronteiriços, na iniciação de diversos argentinos e uruguaios e conseqüente difusão desse sistema religioso nesses territórios, presentificada na patente maioria de terreiros argentinos e uruguaios vinculados com as matrizes mítico-rituais batuqueira e quimbandeira, tipicamente gaúchas, num processo que ganha relevância na da década de $1960^{2}$. Por outro lado, no decorrer desses quase cinqüenta anos, se o fluxo de agentes, técnicas e objetos afro-religiosos do Rio Grande do Sul para esses países ainda está ativo e é importante para a construção do horizonte imaginativo e identitário dos afro-religiosos platinos, também existem uma série de especificidades na constituição das cenas afro-religiosas argentina e uruguaia, que levaram a autonomização e diferenciação dessas cenas em relação à cena religiosa afro-riograndense.

Este artigo aborda algumas açóes e objetos de atores afro-religiosos do sul-brasileiro e do rio da Prata que podem ser lidos dentro do marco da reafricanização. Esta entendida como uma noção polifônica referente aos processos ativos de reincorporação de valores afro-referenciados, no tempo e no espaço, que englobam mobilização política e jurídica; afirmação identitária e/ou de projeto; resgates, apropriações e invençóes de tradiçóes e quaisquer outros objetos que ajudem a formular e expressar a singularidade de uma alteridade, no caso, afro-orientada.

Nesse recorte geográfico e simbólico da circulação afro-religiosa transnacional percebemos que se o processo de reafricanização entre grupos

${ }^{2}$ Ari Oro em Axé Mercosul (1999) registra a importância de 18 pais-de-santo gaúchos entre os pioneiros da difusão platina das religiōes afro-gaúchas (umbanda e quimbanda alinhadas a cosmologia e ritual do batuque, das três a vertente mais africanista). Entre as cidades fronteiriças, o principal destaque se dá para Santana do Livramento e Uruguaiana, a primeira fronteira com o Uruguai e a segunda com a Argentina (Segato, 1998; Bem, 2007, 2008), mas muitas cidades gaúchas próximas a zona de fronteira tem ou tiveram algum pai-de-santo implicado na iniciação de argentinos e Uruguaios, sobretudo Pelotas e Rio Grande, consideradas o berço do batuque ainda no século XIX (Correa, 1988).

Debates do NER, Porto Alegre, ANo io, N. I6, P. 20I-224, JUl./DeZ. 2009 
afro-religiosos ocorre tanto no Rio Grande do Sul, quanto na Argentina e no Uruguai, em cada um desses territórios esse processo interage com construções nacionais, práticas e simbólicas, diversas que influem em formações divergentes nas experiências de reafricanização nos três países.

Longe de esgotar a análise das dimensōes sociológicas relativas a esses processo, o presente texto busca descrever interfaces e soluçóes alternativas que atores contextualizados em uma mesma gramática religiosa podem desenvolver para um mesmo problema quanto estão inseridos e processos nacionais diversos.

\section{A REAFRICANIZAÇÃO NOS TERREIROS DO RIO GRANDE DO SUL.}

O batuque riograndense, similar ao candomblé bahiano, constituiu-se entre as populaçóes negras de Pelotas e Rio Grande ainda no século XIX. Todavia não se sabe se sua gênese está ligada a ação de africanos que desembarcaram diretamente nestes portos, ou a algum negro que tenha vindo de outra região do Brasil. Apesar de todo o preconceito e perseguição com os negros e suas manifestaçóes culturais, o batuque consolidou-se enquanto religiosidade legítima através da luta de seus cultuadores pela visibilidade e contra a discriminaçáo ao longo do século XX e conseguiu a sua difusão para além da população negra e pobre, tendo atualmente uma grande porcentagem de seus seguidores entre pessoas escolarizadas, de classe média e brancas. Além disso, é no Rio Grande do Sul onde mais brasileiros responderam serem afro-religiosos no recenseamento de 2000, sendo o único estado onde, entre 1990 e 2000 não diminuí, mas ao contrário, aumentou em mais de $33 \%$ o número de pessoas autodeclaradas adeptas de religiōes afro-brasileiras. Existe um abismo entre o número de gaúchos autodeclarados afro-religiosos no censo de 2000, 121.180 pessoas, e a realidade de indivíduos que de alguma maneira, mais ou menos efetiva e constante, circulam no meio afro-religioso gaúcho. Mesmo assim, os dados do censo nos apontam que entre os brasileiros autodeclarados afro-religiosos, 23\%

Debates do NER, Porto Alegre, Ano io, N. I6, P. 20I-224, JUl./Dez. 2009 
deles estariam nesse estado, no qual apenas $12,6 \%$ se classificou enquanto preta e parda. Segundo Ari Oro,

A surpresa destas constataçóes resulta especialmente do fato do Rio Grande do Sul produzir sobre si mesmo uma auto-imagem, com repercussóes fora dele, de ser um estado branco, cristão, colonizado e habitado por imigrantes europeus e gaúchos, ofuscando e mesmo excluindo os negros e os índios. (Oro, 2008, p. 10)

Esse é o contexto, de invisibilidade pelo discurso oficial e de resistência ativa por parte da população negra e afro-religiosa na continuidade de seus repertórios culturais, no qual a partir da década de 1980 o processo de reafricanização, tanto no campo político quanto religioso, começou a ampliar-se no Rio Grande Sul.

No Brasil, apesar de uma série de movimentos anteriores pautados na afirmação da herança africana e negra, é a partir de 1978 que vemos emergir do cenário da organização negra, os elementos que constituirão as diretrizes do pensamento político afro-brasileiro, entre estas a própria reflexão sobre a questão da reafricanização. Entre estes acontecimentos, ressaltamos a criação do Movimento Negro Unificado Contra a Discriminação Racial (MNU) em 1978, a partir da reunião de uma série de associações de militância racial, com ideologias identificadas tanto com a luta dos negros dos E.U.A., sobretudo o movimento pelos direitos civis da década de 1960, quanto com a intelectualidade marxista africana em luta pela descolonização. O movimento negro assume um discurso ao mesmo tempo racialista e multiculturalista, ainda lutando contra a segregação, a discriminação, em favor da recuperação da auto-estima do negro, conjuntamente com a revalorização da "herança africana, procurando desvencilhá-la das adaptaçóes e sincretismos com a cultura nacional brasileira". Aliado a isso, o movimento negro amplia os temas em disputa: "para além das discriminaçóes raciais cometidas individualmente, passa-se a combater também a estrutura injusta de distribuição de riquezas, prestígio e poder entre brancos e negros". (Guimarães, 1999, p.211-212). Portanto, naquele momento, o movimento considerava o sincretismo e a

Debates do NER, Porto Alegre, ANo io, N. I6, P. 20I-224, JUl./DeZ. 2009 
mestiçagem como ideologias da conciliação a serviço da manutenção de um status quo dramático para a população negra.

Imediatamente essa nova postura política começou a contaminar os terreiros de todo o Brasil. Na linha de candomblé, no Nordeste e, principalmente, no Sudeste, voltou-se a cultuar Exu, equivalente ao Bará do batuque, como orixá, prática que não ocorria publicamente a mais de cinqüenta anos, e se abandona em parte a visão sincrética dessa entendida com o diabo católico. Nas décadas seguintes muitos terreiros, principalmente os dedicados apenas aos cultos mais próximos da tradiçáo africana, abandonaram as imagens católicas, sincretizadas com os orixás, que antes enfeitavam os quartos-desanto. Muitos grupos, em diversas cidades, dedicaram-se ao aprendizado do idioma ioruba e a pesquisa de rituais antigos, como forma de manutenção e atualização, da tradição, mas também com o sentido de diferenciação de status perante o restante dos terreiros das cenas afro-religiosas locais.

No Rio Grande do Sul, percebi o movimento de reafricanização em três diferentes configuraçôes. Uma primeira que se baseia em um forte diálogo com o Candomblé, referência incontestável no imaginário brasileiro sobre as religiōes de matriz africana. Destarte, mesmo tendo uma existência talvez tão antiga quanto o candomblé, o batuque é ainda hoje considerado por muitos acadêmicos e até mesmo por alguns dos seus praticantes como "um primo pobre" do candomblé ao qual o batuque deveria imitar.

A centralidade dada ao candomblé como religião afro-brasileira mais tradicional, mais legítima e mais próxima das suas raízes africanas advém de fatores tais como a centralização da Bahia, por parte de discursos escolares, acadêmicos, artísticos e midiáticos, como o lugar do negro, e da sua cultura, dentro do Brasil.

Nas salas de aula do Rio Grande do Sul, até alguns anos atrás, não se ensinava quase nada sobre a presença do negro nesse estado e nada sobre sua sociabilidade, música ou religiosidade. Na literatura, sempre que pensamos sobre as religiões afro-brasileiras, nos lembramos de Jorge Amado e de sua obra ímpar, à qual a aceitação do candomblé com lugar positivado no imaginário nacional tanto deve. Academicamente o volume de produção sobre o candomblé ketu em comparação com outros cultos africanistas,

Debates do NER, Porto Alegre, ANo io, N. I6, P. 20I-224, JUl./Dez. 2009 
como o candomblé jejê, o candomblé de Angola, o tambor de mina, o xangô do Recife e o próprio batuque, é altíssimo. No entanto, desde meados da década de 1980, no campo da antropologia e historiografia gaúcha tem-se destacado a apropriação do batuque enquanto objeto de conhecimento e desde então só aumenta o número de estudiosos interessados no tema.

$\mathrm{Na}$ televisão, com a difusão das programações realizadas no sudeste brasileiro, quando aparece algum conteúdo afro-religioso a referência sempre é o candomblé. Nas emissoras gaúchas, em sua restrita grade de programação, eventualmente são noticiadas matérias nos telejornais locais e um casal de sacerdote do batuque mantém um programa vespertino de variedades (Algo Mais, na TV Pampa, retransmissora da rede TV), no qual mantém um quadro fixo de oráculo (jogo de búzios) e matérias sobre a religiāo (forma êmica de referência ao batuque). No rádio e nos jornais porto-alegrenses, na atualidade raramente existe a divulgação do batuque, embora em décadas anteriores sacerdotes como mãe Ieda de Ogum tiveram os seus programas de rádio.

Assim, no Rio Grande do Sul, ocorre um duplo movimento que, por um lado, supervaloriza e exotiza o candomblé e, por outro, ratifica o silêncio sobre o batuque, na escola e nos meios de comunicação. Duas conseqüências desse processo são: na sociedade gaúcha em geral, a reprodução da invisibilidade desse sistema religioso e a indiferença para com o mesmo e, entre alguns afro-religiosos do estado, o entendimento de que o candomblé é a referência legítima da origem histórica e dos fundamentos mítico-rituais do batuque.

Nesse contexto é que muitos sacerdotes têm introduzido: outras cores para a confecção de axós (roupas cerimoniais) e guias (colares rituais), relativas à classificação do candomblé e não do batuque (como o azul para Ogum, ao invés do verde); outros pratos oferecidos aos orixás, como acarajés para Iansã, ou feijão para Ogum, sendo que no batuque tradicionalmente é servido batata doce para a primeira e churrasco de costela para o segundo; um certo sincretismo entre a figura da orixá Nanã Borocum, que não é cultuada no batuque, com o aspecto idoso de Iemanjá; a extensa utilização de nomes sacerdotais, e conceitos rituais em ioruba, em desuso no Rio Grande do Sul,

Debates do NER, Porto Alegre, ANo io, N. I6, P. 20I-224, JUl./DeZ. 2009 
como babalaô (sacerdote responsável pelo oráculo), babalorixá (sacerdote chefe do culto, ao invés de pai-de-santo), baba (ao invés de pai), ilê (ao invés de terreiro ou terreira), etc.

Uma segunda configuração é simetricamente inversa a primeira e se propóe à pesquisa e ao resgate das raízes próprias do batuque, sem a interferência de sincretismos católicos ou kardecistas, muito menos da autoridade do candomblé dentro do contexto nacional. Nessa vertente, muitos pais-de-santo gaúchos, têm se voltado para a literatura acadêmica riograndense, antropológica e histórica, e na valorização do conhecimento dos mais antigos, como formas de pesquisa das raízes e singularidades do batuque e da história negra no Rio Grande do Sul.

Assim, alguns religiosos têm buscado dedicar-se mais ao batuque, do que a quimbanda e a umbanda, realizando um maior número de quinzenas (festas pequenas) durante o calendário litúrgico ou até mesmo realizando apenas o culto aos orixás. De forma mais ampla, as novas geraçôes de batuqueiros tem buscado aprender corretamente as rezas, cantos e saudaçóes em ioruba (o que favoreceu a difusão de centros de ioruba e cultura afro no estado), além da história da África e da escravidão no Brasil, como esteio para conexão dos rituais religiosos contemporâneos com um passado negro, cada vez mais positivado, e com elementos diacríticos da pureza e singularidade africana dessa religião. Exemplos disso podem ser encontrados tanto nos discursos públicos de inúmeros sacerdotes gaúchos, quanto nos endereços dos mesmos na internet, onde além de conteúdos sobre o próprio batuque, ainda encontram-se referências a questão quilombola, aos lanceiros negros ${ }^{3}$ e a história da escravidão.

Essa busca pela afirmação de raízes próprias e pela purificação afroorientada dos rituais afro-religiosos no Rio Grande do Sul, também tem dirigido um maior conhecimento sobre a genealogia das principais linhagens de cada uma das cinco tradiçóes (emicamente, lados ou naçóes) do

${ }^{3}$ Um agremiação de negros que lutavam pelo lado farroupilha, durante a revolução de mesmo nome (1835-1845) e que foram massacrados pelas tropas federalistas em novembro de 1844, quando foram atacados em seu acampamento e já haviam sido desarmados.

Debates do NER, Porto Alegre, Ano io, N. 16, P. 20I-224, JUl./Dez. 2009 
batuque (jeje, ijexá, cabinda, oyó e nagô). Entre pais-de-santo mais jovens, com um grau de instrução e de leitura maiores, a ciência de suas linhagens é até mesmo um símbolo de status. Estes religiosos sabem recitar sua bacia até um bisavô ou trisavô-de-santo, identificam sacerdotes falecidos importantes, não só de sua nação, mas de outras também, tanto de Porto Alegre quanto do interior, e sabem que existe a difusão afro-religiosa para os países do Rio da Prata e quais são os sacerdotes porto-alegrenses que estão nesse fluxo. Não só afro-religiosos universitários, mas qualquer outro com acesso a internet pode levantar informaçóes sobre esses personagens. Primeiro a disseminação dos conteúdos e metodologias pela escola e depois a popularização da disponibilização e pesquisa de dados na rede mundial de computadores permitiu aos afro-religiosos mais novos, completar lacunas de informações que não foram passadas pela geração mais antiga. Isso, de certa forma consolidou o movimento reafricanização da religião e tem permitido a continuidade do batuque enquanto tradição religiosa paralela e autônoma em relação ao candomblé.

Nas cidades de fronteira, Uruguaiana e Santana do Livramento, esse culto público, mas não cerimonioso aos pais-de-santo importantes falecidos, é um objeto para a construção de memória religiosa local. Nomes como os de João do Bará (Exu by ou Bará By), de Teta do Oxalá, em Santana do Livramento, e de Wilson Ávila da Oxum e Ailton Albuquerque da Oxum, em Uruguaiana, são lembrados por todos e estes personagens figuram vários causos. Posto que estes pais-de-santo foram de grande importância na estruturação da transnacionalização das religiōes afro-brasileiras para a Argentina e o Uruguai através da região de fronteira.

Em relação à purificação dos rituais - o desenvolvimento da linha dos africanos na umbanda; a africanização da quimbanda; e a substituição de representações imagéticas sincréticas por outras esteticamente mais africanas no batuque -, não se pode afirmar que alguns dos fenômenos observados tenham uma relação estrita e consciente com o processo de reafricanização, mesmo porque a normalização deles dentro da rede batuqueira antecede cronologicamente o auge do discurso da reafricanização, a partir de 1980. No entanto, estruturalmente, o desenvolvimento desses elementos dentro

Debates do NER, Porto Alegre, ano io, N. I6, P. 20I-224, JUl./Dez. 2009 
do sistema ritualístico batuqueiro (neste ponto, não só gaúcho, mas platino também) responde as mesmas demandas que motivam o processo de reafricanização, a busca pela amplificação dos significados de elementos presentes nesses rituais que se refiram a tradição africana, como vetor constante de identidade cultural e diferenciação social.

A partir de meados do século XX, em terreiros da fronteira gaúcha desenvolvem-se a linha dos africanos, que se caracterizam como uma classe de espíritos de africanos jovens, orgulhosos, bebedores de vinho, zombeteiros e de humor violento. Em sessões que acompanhei no terreiro de mãe Chola em Santana do Livramento, esses espíritos constantemente faziam referência a serem negros e na ausência de negros nas terras argentinas onde haviam outros templos ligados a mãe Chola (Bem, 2007). O porquê do desenvolvimento do culto de possessão dessa falange de espíritos e o significado profundo de performances como as que vi no terreiro de mãe Chola ainda são perguntas sem respostas. Contudo, me parece que em meio a um ritual e cosmologia estruturados como forma de embranquecer e domesticar práticas e narrativas "selvagens" de origem negra e indígena, como foi a umbanda em sua gênese (Ortiz, 1978; Maggi, 1992), a constituição de uma linha ritualística como a dos africanos, que ecoa determinadas narrativas e permite performances de afirmação étnica negra e de estranhamento à lugares onde existe um vazio dessa identidade, parece realocar um elemento latente que anteriormente se tratou de ocultar, inviabilizar, invisibilizar.

Por sua vez, a quimbanda riograndense, aparentada e possivelmente inspirada na macumba carioca, se autonomizou da umbanda e estruturouse como a linha ritual com maior prestígio dentro do sistema religioso batuque, sendo atualmente "o carro-chefe" através do qual muitos adeptos têm se iniciado nos códigos afro-religiosos, posto que essa linha ritual é a que carrega a maior potência de atualização para com o cenário e as necessidades modernas. As entidades cultuadas na quimbanda são o exu e a sua contraparte feminina a pombagira, ambas entidades são ressignificações de divindades tricksters cultuadas na área cultural sudanesa-ioruba, o Exu ou Bará, e na área banto, o Bombogira, do qual derivou a figura pombagira. Esses tricksters, arquétipos do herói civilizador amoral, travesso, de enorme

Debates do NER, Porto Alegre, Ano io, N. I6, P. 20i-224, JUl./DeZ. 2009 
apetite sexual, de índole violenta, sujeito a cóleras, foram tomados pelos missionários cristãos, em serviço na África colonial, enquanto correspondentes ao demônio.

No Brasil, "a partir do início do século XX, o Exu africano, reinterpretado como espírito maroto, mas prestativo, espécie de diabinho familiar da tradição ibérica, começa a se multiplicar nas macumbas do Rio, sob influência das crenças espíritas sobre os mortos" (Capone, 2004, p. 95). As macumbas guardaram muito do imaginário e práticas dos antigos calundus coloniais, um grande acervo de elementos rituais e mitológicos bantos ressimbolizados pelo contato com elementos culturais, iorubanos, europeus e indígenas. $\mathrm{Na}$ macumba, e nas quimbandas do sudeste e do sul que dela evoluíram, o Exu africano transforma-se em uma nova classe de entidades, exus - tipos específicos de eguns (espíritos de mortos) ou de "seres infernais" -, de maneira que várias falanges dessas entidades estão associadas ao cemitério, a reino das encruzilhas, ao reino das almas, a praia (um lugar limite com o mar, que também é um domínio obscuro, por ser traiçoeiro).

Contam os sacerdotes mais antigos que em data anterior a 1960 os exus, ao menos no Rio Grande do Sul, eram cultuados na umbanda, chegando à última gira para limpar as energias negativas. A performance do transe apresentava entidades selvagens e diabólicas que se arrastavam no chão e se comunicavam por grunhidos horripilantes. No entanto, a partir da referida data começaram a aparecer exus que desenvolveram a fala e pediam sacrifícios, roupas, "pompa e circunstância" em rituais próprios. Muitos sacerdotes tanto no Rio Grande do Sul, quanto na Argentina e no Uruguai apontam o Exu Sete das Encruzilhas incorporado pela mãe Ieda de Ogum de Porto Alegre como um dos primeiros nessa nova apresentação.

$\mathrm{Na}$ atualidade, em muitos terreiros gaúchos tenho ouvido narrativas que, sem negar o sincretismo dos tricksters africanos com os demônios judaico-cristãos, dão ênfase ao papel dos orixás na quimbanda. Segundo essas narrativas, os exus seriam escravos de um determinado orixá (Bará ou Ogum são os mais referidos), ou do orixá pessoal de cada adepto. Em determinadas passagens mitológicas do batuque, alguns orixás são identificados como os senhores dos eguns, reis do cemitério/mundo dos mortos. Seriam estes,

Debates do NER, Porto Alegre, ANo io, N. I6, P. 20I-224, JUl./DeZ. 2009 
Xangô, Iansã e Xapanã. Por conseguinte, o culto aos exus e pombagiras tem se reafricanizado de maneira a se tornar um batuque sombrio encabeçado por Exu ou Bará, sendo que cada falange de exus e pombagiras corresponderia a determinado orixá, de maneira que os exus seriam associados com o lado sombrio de cada um desses orixás. Essa nova perspectiva mitológica une ritualmente a linha do batuque com a quimbanda que passa a ser o seu verso, seu lado demoníaco. O que leva a uma nova configuração dos objetos rituais da quimbanda, para que representem essa ligação, na forma de imagens africanizadas dos orixás Bará e Omulu que estariam representando os orixás e seus respectivos exus.

Especificamente na linha ritual do batuque, além dos já referidos interesse pelo ioruba e pela a cultura afro e afro-gaúcha, o mais recorrente exemplo dessa vontade de purificação do culto é a incorporação de estátuas e quadros que esteticamente representem os orixás da forma mais africana imaginável, em detrimento das estátuas e quadros de santos católicos, que no sincretismo equivaleriam aos orixás.

Uma terceira configuração dos processos de reafricanização da cena afro-religiosa gaúcha passa pela atuação de diversas federações (CEDRAB, AFROBRAS, Fundação Moab Caldas, FORMA/RS, CEUCAB, OSECAE, AFRORITO, Associação de Mulheres Afro umbandistas, Afroconesul, Aliança Umbandista), que têm atuado na luta pela proteção dos direitos de expressão e ofício afro-religiosos, na conscientização da população quanto a tolerância religiosa. Assim, grupos como a Fundação Moab Caldas, liderada pelo babalorixá de candomblé Áureo de Ogum, realiza ao menos duas vezes por ano atividades de divulgação religiosa e de luta contra a intolerância étnico-religiosa em um palco armado defronte do mercado público de Porto Alegre; a CEDRAB (Congregação em defesa das religiōes afro-brasileiras) realiza diversos seminários, têm representantes em comissões governamentais sobre a questão religiosa e teve um papel decisivo no caso da disputa pública sobre a tentativa de aprovação de uma lei contra o sacrifício ritual de animais na Assembléia Legislativa gaúcha no ano de 2005 (Oro, 2005; Ávila, 2006).

Essa nova forma de ativismo afro-religiosa, demarcando um lugar de

Debates do NER, Porto Alegre, Ano io, N. I6, P. 20I-224, JUl./Dez. 2009 
ação dentro da esfera pública através de uma atuação jurídico-política é recente, mas tem se mostrado importante como forma de articulação da minoria afro-religiosa com demandas da população negra e com o próprio movimento negro brasileiro e promovido a uma ampliação da participação política de vários sacerdotes afro-religiosos. De forma que:

as alianças recentes com dirigentes do Movimento Negro, políticos e grupos provenientes de outros estados tiveram papel importantíssimo, não só no episódio envolvendo o Código de Proteção aos Animais, como nas açóes que se seguiram. $\mathrm{O}$ apoio institucionalizado de um grupo com extensa trajetória de lutas, como é o caso do Movimento Negro, a participação pública de políticos ao lado dos africanistas, bem como a parceria da prefeitura de Porto Alegre, ao instituir uma comissão oficial de religiosos e membros do poder municipal, conferiram maior abertura às religióes afro-brasileiras e ampliaram sua rede de apoio. A valorização e a defesa da religiosidade de matriz africana passaram, dessa forma, a ser realizadas também por outros grupos. Além disso, essas alianças evidenciaram que a reação promovida pelos africanistas não foi em vão. (Possebon, 2007, p.169)

Descritas, de forma reduzida, as três configurações do processo de reafricanização que percebi na cena afro-religiosa gaúcha, trato de na continuação desse texto realizar o mesmo movimento para as formas, que consegui compilar, da reafricanização na Argentina e no Uruguai.

\section{A REAFRICANIZAÇÃO NOS TERREIROS DA ARGENTINA}

Apesar de referências a uma grande população negra na Argentina colonial e do século XIX, sobretudo em Buenos Aires, por surtos de enfermidades, mortandade dos homens nas guerras e taxas de fecundidade baixas, $o$ elemento negro quase desapareceu do território argentino, não obstante, se sabe da importância de uma população residual de descendentes de negros em cidades como Córdoba e Corrientes, por exemplo. E no decorrer do

Debates do NER, Porto Alegre, ANo io, N. I6, P. 20I-224, JUl./DeZ. 2009 
século XX a imigração de afro-caribeños e africanos incrementou o contingente dessa população, que, no entanto, continua praticamente invisível no imaginário argentino, ao ponto de que até a pouco tempo atrás não havia o interesse em se pesquisar censitariamente a porcentagem dessa população.

Por sua vez, as religióes afro-brasileiras adentram o território argentino a partir da década de 1960, por influência da ação de três grupos de sacerdotes: a) argentinos que residiram e se iniciaram na religião no Brasil ou no Uruguai e voltando a Argentina começaram a viver da religião; b) argentinos fronteiriços, sobretudo de cidades como Paso de los Libres e Santo Tomé, que tinham contato com a cena afro-religiosa de cidades brasileiras limítrofes e c) pela ação religiosa de pais-de-santo brasileiros e uruguaios em Buenos Aires e no interior geralmente por iniciativa de argentinos identificados nos dois primeiros grupos (Oro, 1999; Bem 2008). Contemporaneamente, segundo a Primera Encuesta sobre Creencias y Actitudes Religiosas en Argentina, realizada pelo CEIL PIETTE/ CONICET em 2008, estimasse que nem um $1 \%$ da população é afro-religiosa e que dos que são, a maioria se encontra na capital federal e nas cidades de seu conurbano ${ }^{4}$.

Dentro do cenário afro-religioso argentino podemos identificar, duas formas de expressão do processo de reafricanização. Uma forma que têm relação com a purificação dos rituais do sistema afro-religioso, por apropriações exógenas ou não, o que levou muitos afro-religiosos argentinos iniciados no batuque à migrarem desse sistema afro-religioso para outros, como o cubano e o nigeriano, considerados ainda mais puros; e, por fim, uma outra forma de ação baseada promoção da cultura negra e afro-religiosa, em conjunto (ou não) com as coletividades étnicas negras migradas, buscando estabelecer conexóes entre as práticas afro-religiosas atuais e o passado negro argentino.

No marco do primeiro movimento, ocorre que os afro-religiosos argentinos se ressentem pela forma com que vários sacerdotes brasileiros abusaram da sua ignorância (técnica) e não os iniciaram verdadeiramente,

${ }^{4}$ Alguns dados dessa enquete estão disponíveis no site do CEIL-PIETTE: <http://www. ceil-piette.gov.ar> (acesso setembro de 2008).

Debates do NER, Porto Alegre, ANo io, N. I6, P. 20I-224, JUl./Dez. 2009 
fazendo sacrifícios, assentamentos e outros objetos (ações) religiosos que posteriormente seriam identificados como falsos. A partir dessa memória de abuso e de uma situação de déficit ritualístico, muitos pais-de-santo têm buscado complementação litúrgica estudando o Ifá nigeriano, os cultos afro-cubanos (santería, regla de Ocha), por vezes até buscando sacerdotes que os iniciasse nessas práticas, mas sem a confiança de anteriormente fora depositada nos brasileiros, como me relatou iya Peggy de Iemanjá (Florida, Vincete Lopez, grande Buenos Aires).

Essa sacerdotisa é a figura mais importante nesse processo de iniciação e apropriação de práticas rituais afro-religiosas nigerianas, como forma de purificação do batuque argentino, considerado por seus próprios adeptos como incompleto. Iya Peggy de Yemonja, mãe-de-santo do batuque, foi iniciada em 1977 pelo pai Adão de Oxalá, gaúcho de Viamão, depois de ter participado alguns anos da comunidade de mãe Nélida de Oxum (a primeira argentina com templo oficialmente aberto nesse país). Iya Peggy também é Iyaonifa, sacerdotisa, do Ifá nigeriano, um sistema de adivinhação que se perdeu nos cultos brasileiros, mas que existe em Cuba em uma versão adaptada. Antes de se tornar batuqueira tinha uma escola de inglês e demonstra claramente a importância da cultura educacional moderna na forma como vive e transmite os objetos afro-religiosos, na postura professoral como que difunde a religião: organizando seminários, participando ativamente de fóruns de debate na internet, dialogando com lideranças afro-religiosas do mundo todo e, a partir desse trabalho, descobrindo elementos para preencher as várias lacunas dos mitos, rituais e da teologia batuqueira em seu país.

Com maior ou menor fundamentação em pesquisas acadêmicas e contatos com autoridades religiosas africanas, outros pais-de-santo também se empenham na purificação dos rituais de linha-cruzada (batuque, umbanda e quimbanda), amplificando a africanidade dos objetos religiosos, como comentei no caso da quimbanda no Rio Grande do Sul. E, nesse caso específico, é muito interessante a forma como mãe Karina de Oxum, de Los Polvorinos (Malvinas Argentinas, grande Buenos Aires), iniciada no batuque e na quimbanda por mãe Ieda de Ogum (de Porto Alegre) con-

Debates do NER, Porto Alegre, Ano io, N. I6, P. 20I-224, JUl./Dez. 2009 
seguiu realizar em seus rituais essa apresentação carregada de uma estética (imaginada africana) referida naquilo que eu nominei anteriormente de "um batuque sombrio".

Em relação à segunda forma de reafricanização entre os afro-religiosos argentinos, existe na esfera pública a ação de algumas federações religiosas, Metropolitana, A.S.R.A.U (Agrupación social religiosa africanista y Umbandista)Senquanto promotoras de açôes culturais (seminários, procissões, mostras de cultura de origem africana etc. $)^{5}$, muitas vezes conjugado ações com outros grupos negros desse país, formados, sobretudo, e como citado anteriormente, por emigrados africanos e afro-caribenhos. O objetivo dessas açôes é dar visibilidade e agregar legitimidade os cultos afro-religiosos, retirando-lhes o estigma de serem considerados como seitas.

Entre os pais-de-santo com os quais trabalhei na capital platina, o que mais trabalha dentro desse segundo movimento de reafricanização é o pai Alfredo Echegaray de Ogum iniciado na umbanda, no ano de 1973, pelo pai argentino Hugo Carlos de Oxalá. Bastante ativo na cena buenaeirense, preside uma federação afro-religiosa chamada Metropolitana; participa de várias atividades de divulgação da cultura negra e afro-religiosa, sendo divulgador da revista virtual afro-argentina Quilombo. Estive na casa desse sacerdote, no bairro de Mataderos, cidade de Buenos Aires, em duas ocasióes durante o mês de setembro de 2008. Em uma dessas oportunidades pai Alfredo falou longamente sobre a presença negra na Argentina colonial. Como Alejandro Frigerio apontou, este tipo de discurso que tenta colar a experiência afro-religiosa com uma memória sobre a presença negra no passado nacional não deixa de ser uma estratégia de legitimação dessa religiosidade exógena, através da sua aproximação com categorias do imaginário e história argentina. Dessa presença negra anterior, quase nada restou demograficamente e a cultura lingüística, musical, culinária, herdada

\footnotetext{
${ }^{5}$ Além dos já citados Alfredo de Ogum e Peggy de Yemonja, encontrei ainda três pais-desanto da Grande Buenos Aires que desenvolvem açóes desse tipo. Sáo estes, Hugo de Oxalá, de Tigre, Hugo de Iemanjá, da capital federal, e Santiago Allegue de Ogum, de Quilmes. Todavia, contatos mais aprofundados com estes, para uma melhor exposição de suas trajetórias, são um dos pontos a serem desenvolvidos na continuação dessa pesquisa.
}

Debates do NER, Porto Alegre, Ano io, N. I6, P. 20I-224, JUl./Dez. 2009 
dos negros foi durante muitos anos invisibilizada. A seguir apresento uma cena etnográfica a partir de um excerto da entrevista que realizei com pai Alfredo de Ogum (Barrio Mataderos, Buenos Aires, Província de Buenos Aires, Argentina. Setembro de 2008).

Pai Alfredo me contava sobre a estrutura de ação da federação Metropolitana, de como os membros da diretoria debatiam entre si sobre os fundamentos ritualístico de cada linha, para compor um corpo ritualístico padrão. "Tenemos igualdades múltiples e desigualdades mínimas. Es sencillo, porque es la única forma de estructurar una parte religiosa, que es la que no tenemos, puesto que todos hablamos desde la oralidad. Porque la gran mayoría de las cosas o secretos lindos o muy fuertes, se han perdido porque los viejos sacerdotes no lo han transmitido. Hoy damos cosas escritas, hay libros: el de Ari Pedro, Alejandro Frigério con sus tratados. Hay montones, Caribé, hay montón de escritores que han ido sacando las raíces, Fatumbi Verger. Y la historia afro en la argentina es tan antigua como en Brasil, acá hay negros del año 1600. Está comprobado por la trata de negros en el Río de la Plata del Studer, que en el 1605 el cabildo pierde supuestamente las actas cuando tenían el puerto cerrado y había 2 millones de negros que traían los barcos negreros. O sea que más o menos se calcula que entre 1585 y el 1700 se trajeron alrededor entre 3 y 5 millones de personas que al menos pasaron por Argentina”. Diante de tantas informaçóes que revelam um passado argentino com uma demografia negra alta, só pude fazer uma constatação. "Que cosa, y parece que no queda casi nada". Pai Alfredo, aproveitou o "gancho" e continuou com sua aula. "No quedan, y de piel negra, negros, no quedaron, porque los buenos patricios, como le decían a la gente de ese momento, los enviaron a todos, a luchar con San Martín, a cruzar los Andes, a la guerra del Paraguay, y los mandaron a todos a luchar. Hay anécdotas, de que San Martín en una de las batallas, no me acuerdo ahora, lo he leído, pero no me acuerdo del dato, dice: 'pobres negros los están matando pero son los únicos que pelean'. Entonces nosotros tenemos una tradición negra, si! Lo que pasa es que no la supimos conservar. En Brasil quizás se pudieron conservar más porque se metieron en los Palmares, en los quilombos, se escondieron más. Acá mucho 'Palmar' [sic.] y quilombo no había, el negro que era bajado en el Río de la Plata iba a Córdoba, lo llevaban a Jujuy a Salta, a las minas, y ahí se perdió el rastro. Pero sabemos de anécdotas de negros antiguos, sea del negro Flores, que era un negro que estaba en una feria en Córdoba y 'Tacuaba' [sic.],

Debates do NER, Porto Alegre, Ano io, N. I6, P. 20I-224, JUl./DeZ. 2009 
por la zona centro, y contaba, en el ano 1610 1612, historias de los negros, y que hay historias, 'ponele', de que en el 1615 más o menos se hacia una obra de teatro que se llamaba El brujo doctor, en la cual entre comillas dice que los negros jugaban el opelé [búzios] como en Cuba, los collares le dicen ellos, los collares como en Cuba y Brasil, la macumba. La negra Mercedes en San Telmo, hacia adivinación para los blancos; el mismo Rosas en su época iba a los tangos de Mina y Angola, se sentaba con el rey de Mina y Angola y presenciaba los bailes. Cuando hablamos de bailes, nos queda la gran duda, era un baile, o algo religioso disfrazado? (...) Todo eso, hace mucho tiempo y diríamos que hubo un rescate religioso a partir de 1980 con el fin de la dictadura y el comienzo de la democracia, en el año 83, hay una gran expansión religiosa, o sea los templos pudieron abrir sus puertas porque antes era toque de palmas y cantar bajito y bueno no había una expansión. El argentino que quería hacer religión o que había encontrado un amigo que le decía que una religión era así, se iba a Brasil, o cruzaba a Uruguay, no hacía religión acá, iba una vez al mes a Brasil o más a Uruguay, y hacía religión en Uruguay, no hacía religión en Argentina. Después del año 83 con la venida de la democracia se empiezan a abrir las casas de religión.

Nessa extensa fala de pai Alfredo pode-se vislumbrar o eixo de seu argumento: a Argentina desde antes tinha uma cultura negra com a sua própria dinâmica religiosa e que depois da abertura democrática, o culto importado do Brasil e/ou do Uruguai pôde revelar-se como uma forma de resgate dessa antiga tradição, por ser seu equivalente, mantido pelos negros brasileiros. No meu entender, essa é uma forma tanto de render homenagens a essa tradição perdida, quanto de construir um passado e uma legitimidade contando com a mediação de material acadêmico, como qualquer indivíduo ilustrado e em um movimento muito parecido com o que descrevi no caso gaúcho da relação dos afro-religiosos com a literatura acadêmia ${ }^{6}$.

Nas duas formas de reafricanização entre os afro-religiosos argentinos, percebemos: a importância desse processo como forma de manutenção e

${ }^{6}$ Dois sociólogos argentinos, Peter Brieger e Joaquin Algranti, em conversas informais, disseram que a história era na Argentina, entre as ciências humanas, enquanto formadora de opinião, a mais valorizada socialmente.

Debates do NER, Porto Alegre, Ano io, N. 16, P. 20I-224, JUl./Dez. 2009 
radicalização purificadora da tradição batuqueira gaúcha, mesmo que seja pela incorporação de práticas e significados relativos à outras tradiçôes afroreligiosas e a necessidade de um maior colamento a própria tradição histórica nacional em uma militância, que diferentemente do Rio Grande do Sul e do Uruguai (como veremos a seguir), de divulgação cultural que tem uma importância política, quando revela um grupo religioso invisibilizado, mas que não age nos marcos do campo político institucionalizado.

\section{A REAFRICANIZAÇÃO NOS TERREIROS DO URUGUAI}

Dos três países imbricados nesse processo da transnacionalização afroreligiosa transfronteiriça (Bem, 2007), certamente é no Uruguai que se percebe com mais rapidez e clareza a importância de diversos fluxos, não só socio-religiosos, mas lingüísticos, demográficos e culturais que circulam entre o Brasil (com maior densidade no sul-brasileiro), o Uruguai e a Argentina (com maior densidade nas províncias limítrofes com o Brasil e Uruguai, bem como na capital federal). Calcula-se que durante o período colonial uns $20 \%$ da população era de escravos, a maioria vinda do Brasil pela fronteira ou diretamente ao porto de montevidéu e que a maioria desses escravos era utilizada em serviços domésticos. A abolição da escravatura na Banda Oriental ocorreu em 1853, mas até a abolição no Brasil, os dois governos mantinham um acordo de extradição de cativos foragidos e muitos estancieiros gaúchos que tinham terras nos dois lados da fronteira organizavam expediçóes de captura de negros no Uruguai. Durante o conturbado século $\mathrm{XIX}$, muitos escravos eram recrutados para as campanhas militares e para os libertos uma das melhores opções de ascensão social era o ingresso no serviço militar, o que levou a uma considerável diminuição dessa população em razão das inúmeras invasões (britânicas, brasileiras, argentinas), da guerra civil entre blancos e colorados e da Guerra do Paraguai (1864-1870).

$\mathrm{Na}$ atualidade, de uma população em torno de 3.500.000 habitantes, segundo dados da Encuesta Nacional de Hogares Ampliada do ano de 2006

Debates do NER, Porto Alegre, ANo io, N. I6, P. 20I-224, JUl./DeZ. 2009 
realizada pelo INE (Instituto Nacional de Estadísticas) uruguaio, mais de 300 mil destes são considerados de ascendência afro ou negra $(9,1 \%$ da população), tendo uma forte presença em Montevidéu e nos departimentos da fronteira com o Brasil?.

Se houveram ou não importantes instituições religiosas afro-uruguaias no período colonial e no século XIX, o certo é que estas não sobreviveram até a contemporaneidade e o grande aporte cultural dos negros uruguaios foi a sua influência na música, em gêneros como a payada, a milonga, o tango e o candombe ${ }^{8}$. Este último gênero de música, baseado em conjuntos rítmicos formados por três tipos de tambores, foi introduzido no Uruguai por negros bantos. Tradicionalmente a corda, o conjunto de tamboreiros, é acompanhado por três personagens: El escobero, el gramillero e la mama vieja, contemporaneamente foi introduzida a figura da vedete. Entre o meio acadêmico uruguaio, especula-se que o candombe em sua gênese teria um teor mais religioso que profano e que os personagens que o acompanham seria representaçôes de feiticeiros. Também conta-se que na execução dos toques, alguns tamboreiros sentem um presença estranha, como se alguém os ajudasse a tocar. No entanto, o candombe é uma manifestação festiva laica e sobre essa é que está construída a identidade do negro montevideano. É pela prática do candombe que alguns atores descobrem a história local, de seus bairros, das lutas da coletividade negra, da herança africana nos tambores. Ai está o culto aos antepassados e a mobilização cultural do presente. De forma que entre os negros montevideanos, poucos se encantaram pelo batuque, talvez por terem sua identidade negra muito bem assentada sobre

${ }^{7}$ Os dados demográficos do Uruguai estão disponibilizados no site do INE: <http://www. ine.gub.uy> (acesso em setembro de 2009).

${ }^{8}$ Nos departamientos que fazem fronteira com o Brasil, a influência do candombe e do tango é limitada. A payada, a milonga e outros estilos de música gaúcha transfronteiriça e o samba brasileiro são a referência musical popular. Obviamente, essa incorporação de objetos culturais brasileiros pelos uruguaios da fronteira não para na música. $\mathrm{O}$ intercambio sócio-cultural, nas mais diversas esferas é explícito. Tal dado leva com que muitos uruguaios digam que existem dois Uruguais divididos pelo Río Negro, sendo que a parte norte teria uma configuração cultural muito mais próxima do Brasil que de Montevidéu.

Debates do NER, Porto Alegre, ANo io, N. I6, P. 20I-224, JUl./DeZ. 2009 
o candombe. Assim, no Uruguai, apesar de algumas exceçôes, negritude e religiōes afro-brasileiras, não necessariamente se misturam, produzindo um discurso afro-religioso completamente auto-referido que pouca ou nenhuma referência ao passado negro uruguaio, apenas aos personagens que trouxeram a religião à este país a partir dos anos 1930, nos departamentos da fronteira e a partir de 1940 na capital (Bem, 2008).

Segundo a mesma enquete do INE a porcentagem de adeptos da umbanda ou religiōes afro-americanas seria em torno de $0,6 \%$ no total da população do país e de 1\% em Montevidéu. Na cena afro-religiosa uruguaia pode-se compilar e perceber duas vertentes do processo de reafricanização: a primeira trabalha pela valorização e manutenção das tradiçōes afro-religiosas brasileiras e a segunda essa do encontro das demandas e ações religiosas e político-identitárias pela legitimidade da expressão cultural afro-orientada na esfera pública.

Sobre a primeira vertente pode-se dizer que como no Rio Grande do Sul há quase que como um culto público aos pais-de-santo difusores das linhagens, no caso uruguaio os percursores da transnacionalização, aos pioneiros uruguaios e aos grandes representantes da religião no país. Em fevereiro de 2006, participei de uma Curimba de exus, reunião de vários terreiros para um grande ritual, organizada pelos sacerdotes Susana de Andrade e Julio Kronberg. Nesta festa muitos pais-de-santo foram homenageados e registrei que todos esses pais-de-santo fizeram referência ao pai Joãozinho do Bará, à mãe Teta, à mãe Maria das Matas e ao pai Armando Ayalla. Os dois últimos respectivamente: a primeira sacerdotisa a abrir terreiro em Montevidéu, ainda na década de quarenta; e, o segundo, o nome mais destacado de toda a história da religião afro na capital uruguaia, promotor da religião em programas de rádio, em associaçóes culturais, em livros, falecido no final dos anos 1990.

Ainda dentro dessa vertente, é cabal a supremacia do batuque sobre o candomblé e a quase inexistência de sacerdotes iniciados na santeria cubana e no ifá nigeriano, apesar da divulgação de alguma literatura sobre os temas nas santerias (lojas de artigos religiosos) montevideanas. O Brasil é a grande referência afro-religiosa e Porto Alegre é a cidade símbolo da tradição batuqueira, embora a Bahia sempre seja referida como o berço da tradição afro-religiosa brasileira e como o destino sonhado para uma

Debates do NER, Porto Alegre, ano io, N. I6, P. 20I-224, JUl./Dez. 2009 
verdadeira interiorização da filosofia negra, de maneira bem semelhante ao que se percebe na Argentina.

Em relação aos processos de reafricanização que implicam tanto o campo religioso quanto o político na mobilização pela afirmação e legitimação identitária, é o do grupo Atabaque, encabeçado pela mãe Susana de Andrade e pelo pai Júlio Kronberg o principal referente nessa vertente de atuação. Esse grupo aposta tanto na construção de uma bem estabelecida rede de relações religiosas com pais-de-santo porto-alegrenses e da fronteira, quanto na construção de uma frente afro-religiosa com ativismo cultural e pretensóes políticas. Esse grupo possui, há aproximadamente 10 anos, um jornal homônimo sobre as religióes afro-umbandistas ${ }^{9}$ no Uruguai e encontram-se ligados à AFROCONESUL, uma confederação internacional (presidida pelo pai-de-santo porto-alegrense Toni de Oxalá) que legitima perante as autoridades nacionais as casas de cultos afro-brasileiros.

Em outra frente, o grupo Atabaque atua na esfera pública lutando contra os ataques da Igreja Universal uruguaia contra as religióes de matriz africana; por sua atuação foi suspenso um programa da citada Igreja em um dos canais públicos do Uruguai. Pai Júlio e mãe Susana, também são pessoas públicas de bastante prestígio: ela tem uma coluna semanal em um importante diário de Montevidéu e ele é um dos membros da Unidad de antención a diversidad cultural da intendencia montevideana; os dois iniciam, paramentados de orixás, o desfile dos grupos de candombe, no carnaval uruguaio; realizam uma cerimônia, bastante concorrida, para Iemanjá, em uma área nobre da capital; além de realizarem anualmente uma festa de aniversário para o jornal Atabaque, na qual são entregues troféus para os pais-de-santo do ano e para os políticos amigos das causas afro-umbandistas.

Por duas vezes, durante os processos eleitorais uruguaios, o grupo Atabaque lançou pai Júlio como candidato a cargos no legislativo, com re-

9 O termo é de uso corrente no Uruguai, mesmo entre os afro-religiosos identificado com a tradição brasileira. No entanto, a substituição do termo afro-brasileiro por afroumbandista, aumenta o peso do elemento africano e diminui as marcas da brasilidade original. A mudança dá relevância à umbanda, sincrética com o catolicismo e com o kardecismo, formas de espiritualidade lá praticadas.

Debates do NER, Porto Alegre, Ano io, N. 16, P. 20I-224, JUl./DeZ. 2009 
sultados expressivos, mas não suficientes. E para o pleito ao senado nacional do corrente ano, tanto pai Julio quanto mãe Susana estão vinculados como candidatos em uma sub-lista do grupo de José "Pepe" Mujica, candidato à presidência pelo Frente Amplio. Interessante assinalar que mesmo tendo excelentes relaçôes com o movimento negro uruguaio, sobretudo com o grupo Mundo Afro (organização negra do Uruguai) o discurso político desses sacerdotes não é voltado exclusivamente para a coletividade negra e afro-religiosa, incorporando demandas de várias minorias étnicas e culturais, como as dos grupos indígenas uruguaios, ciganos, dos moradores dos asentamientos irregulares, e dos falantes do D.P.U (sigla para dialeto português no uruguai, o equivalente ao nosso portuñol).

Finalizada essa sucinta descrição das duas vertentes mais representativas da reafricanização na conjuntura afro religiosa uruguaia passemos às reflexôes que encerram o argumento deste texto.

\section{CONSIDERAÇŌES FINAIS}

A cena afro-religiosa transnacional entre o sul-brasileiro, a Argentina e o Uruguai é um fenômeno complexo que envolve agentes, ações e objetos religiosos, étnicos e nacionais não só dos três países referidos, mas também da África, de Cuba, em relaçôes pessoais, virtuais e imaginárias das mais variadas, que não podem ser resumidas em um texto desse formato.

No entanto, podemos afirmar que, macrossociologicamente, ser seguidor, de uma das vertentes das religióes de matriz ou presença africana - ou, o que, em termos genéricos, se representa como ser um religioso "afro- $\mathrm{x}$ ", onde, $\mathrm{X}$ é qualquer referente qualificativo relativo a diferentes contextos étnicos, nacionais, religiosos etc. Por exemplo, afro-gaúcho, afro-uruguaio, afro-umbandista - pode modificar a inserção dos indivíduos dentro dos esquemas étnicos, políticos, de classes sociais, existentes em uma "sociedade nacional", na medida em que são diversas as formas destas religiosidades acomodarem-se aos imaginários e práticas existentes em cada sociedade. Além disso, a ação dos seus praticantes na busca da conversão de fiéis ou da

Debates do NER, Porto Alegre, ANo io, N. I6, P. 20I-224, JUl./DeZ. 2009 
obtenção de espaço discursivo, midiático e de direitos na esfera da sociedade civil organizada se utiliza de diferentes aportes para sua consecução.

Com vimos ao longo desse texto, encontramos exemplos bem claros dessa diferenciação nacional nos processos de reafricanização, suas formas de luta política pela liberdade religiosa e legitimidade da sua expressão pública. Enquanto no Brasil tal luta, mesmo sendo um pouco distinta, está incorporada na causa da valorização das populaçôes afro-brasileiras e suas culturas, no Uruguai esses dois campos de mobilização não se encontram tão articulados, levando um grupo afro-religioso uruguaio com pretensóes políticas a somar suas reivindicações às de outras minorias, como as indígenas. $\mathrm{Na}$ Argentina, que entre os três países é onde a presença demográfica e memória negra são menos visíveis, percebemos que a reivindicação dos direitos afro-religiosos faz-se em termos que oscilam entre o modelo brasileiro e o uruguaio. Ora a mobilização é pelo reconhecimento das minorias religiosas, mais próximo do exemplo uruguaio, ora encadeia-se à visibilização da negritude argentina, organizada principalmente pelas coletividades africanas e afro-caribenhas emigradas recentemente, postura essa mais próxima do caso brasileiro, mesmo que com uma "maior timidez" e uma menor relevância sócio-política.

\section{REFERÂNCIAS BIBLIOGRÁFICAS}

ÁVILA, Cíntia Aguiar de. Apanijé ("Nós matamos para comer"): Uma análise sobre o sacrifício de animais nas religiōes afro-brasileiras. Monografia de conclusão em Ciências Sociais. UFRGS, Porto Alegre, 2006. Mimeo.

BEM, Daniel F. Caminhos do axé: a transnacionalização afro-religiosa para os países platinos a partir do terreiro de Mãe Chola de Ogum, de Santana do Livramento - RS. 2007 (Dissertação de Mestrado).

. A preponderância das fronteiras geográfica e simbólica na transnacionalização afro-religiosa no Prata. In: ORO et all. Debates do NER, ano 9, $\mathrm{n}^{\circ} 13$, jan./jun. de 2008, p. 25-46.

CAPONE, Stefania. A Busca da África no Candomblé: tradição e poder no Brasil. Rio de Janeiro: Contra Capa/Pallas, 2004. 375p.

Debates do NER, Porto Alegre, Ano io, N. 16, P. 20I-224, JUl./DeZ. 2009 
CORREA, Norton F. Os vivos, os mortos e os deuses: um estudo antropológico sobre o Batuque do Rio Grande do Sul. 1988. 475 f. Dissertação (Mestrado) Departamento de Programa de Pós-Graduação em Antropologia, Universidade Federal do Rio Grande do Sul, Porto Alegre, 1988.

FRIGERIO, Alejandro. Estabelecendo pontes: articulação de significados e acomodação social em movimentos religiosos no Conesul. In: Oro, Ari P. \& Steil, Carlos A. (org.). Globalização e religiāo. Petrópolis: Vozes, 1997, p. 153-178.

GUIMARĀES, Antonio Sérgio Alfredo. Racismo e anti-racismo no Brasil. São Paulo: Ed. 34, 1999. 238 p.

MAGGIE, Yvonne. Medo do feitiço: relações entre magia e poder no Brasil. Rio de Janeiro: Arquivo Nacional, 1992.

ORO, Ari Pedro. Axé Mercosul: as religiōes afro-brasileiras nos países do Prata. Petrópolis: Vozes, 1999.

- O sacrifício de animais nas religióes afro-brasileiras: análise de uma polêmica recente no Rio Grande do Sul. In: Religião e sociedade. Vol. 25, n. 2, 2005, p. 11-31.

.As religiôes afro-brasileiras do Rio Grande do Sul. In: ORO et all. Debates do NER, ano 9, no13, jan./jun. de 2008, p. 9-23.

ORTIZ, Renato. A morte branca do feiticeiro negro: umbanda: integração de uma religião numa sociedade de classes. Petrópolis: Vozes, 1978.

POSSEBON, Roberta Motin. A reação das religióes de matriz africana no Rio Grande do Sul: conflitos com neopentecostais e defensores dos animais. Dissertação (Mestrado em Ciências Sociais)- Faculdade de Filosofia e Ciências Humanas, PUC/ RS, Porto Alegre. 2007, 174p.

SEGATO, Rita Laura. Fronteiras e Margens: a história não contada da expansão religiosa afro-brasileira para a Argentina e o Uruguai. Religião e Sociedade. Rio de Janeiro, volume 19, número 1, junho 1998, p. 113-129.

Debates do NER, Porto Alegre, ano io, N. I6, P. 20I-224, JUl./DeZ. 2009 